\title{
Inheritance of seed size in watermelon populations
}

\section{Herencia del tamaño de la semilla en poblaciones de sandía}
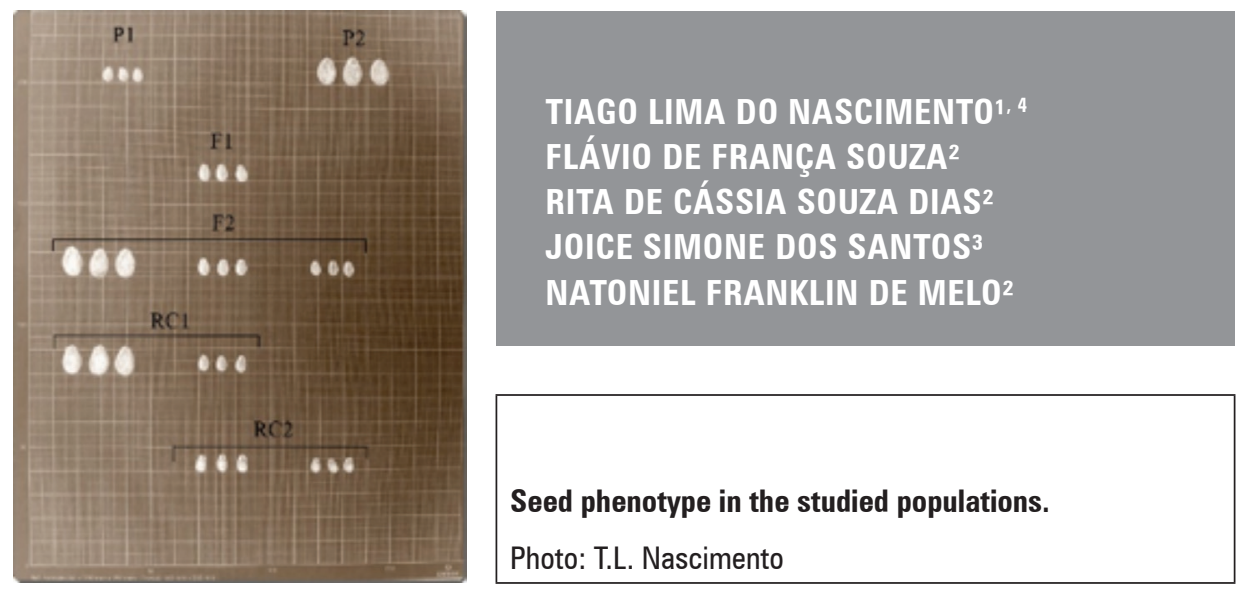

\section{ABSTRACT}

Seed size is an important agronomic trait and is applicable to different abilities. Small seeds guarantee the greater use of the pulp, while larger seeds facilitate sowing. However, there is little work on the genetic control of this characteristic in watermelon. The objective of this work was to study the seed size inheritance in watermelon populations by crossing contrasting genotypes, seeking to gain information to provide technical support during the selection of seed size for the development of new watermelon genotypes. The seed lengths of six populations, $\mathrm{P}_{1}, \mathrm{P}_{2}, \mathrm{~F}_{1}, \mathrm{~F}_{2}, \mathrm{BC}_{1}$ and $\mathrm{BC}_{2}$, were measured using the GENES software segregating and nonsegregating generations procedure. This trait is controlled by two genes with incomplete dominance. In addition, depending on the populations studied, inheritance for the characteristic in question may behave differently. Nevertheless, the selection of superior individuals within populations can be performed based on this phenotype, which allows the exploitation of these individuals within breeding programs to develop lines or hybrids.

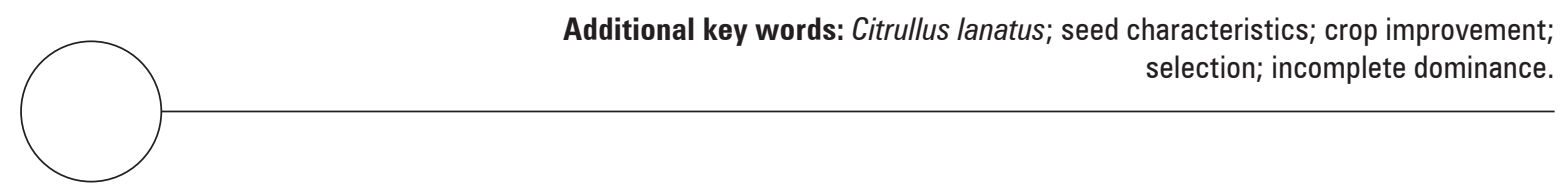

\footnotetext{
Feira de Santana State University, Fundação de Amparo à Pesquisa da Bahia; CAPES Scholarship Student in Plant Genetic Resources, Department of Biological Sciences, Feira de Santa (Brazil). ORCID Nascimento, T.L.: 0000-00020916-6344

2 Embrapa, Brazilian Semiarid Agricultural Research Corporation, Genetics and Plant Breeding, Petrolina (Brazil). ORCID Souza, F.F.: 0000-0002-9632-2666; ORCID Dias, R.C.S.: 0000-0002-5527-3693; Melo, N.F.: 0000-0001-68884090

3 Federal Institute of Education, Science and Technology of Ceará, Crateus (Brazil). ORCID Santos, J.S.: 0000-00033597-2021

4 Corresponding author. tiago_lim.a@hotmail.com
} 


\section{RESUMEN}

El tamaño de las semillas es un rasgo agronómico importante, pudiendo utilizarse para diferentes habilidades. Mientras que las semillas pequeñas garantizan un mayor aprovechamiento de la pulpa, semillas más grandes facilitan la siembra, sin embargo, existen pocos trabajos sobre el control genético de este carácter en la sandía. El objetivo de este trabajo fue estudiar la herencia del tamaño de las semillas en poblaciones de sandía cruzando genotipos contrastantes, buscando proporcionar soporte técnico durante la selección del tamaño de la semilla en el desarrollo de nuevos genotipos de este fruto. Fue medida la longitud de la semilla de seis poblaciones $\mathrm{P} 1, \mathrm{P} 2, \mathrm{~F} 1, \mathrm{~F} 2, \mathrm{RC}_{1}$ y $\mathrm{RC}_{2}$ utilizando el procedimiento generaciones segregantes y no segregantes (GENES), por medio del cual fue posible concluir que la herencia del tamaño de semillas en las poblaciones estudiadas es controlada por dos genes con dominancia incompleta. Además, dependiendo de las poblaciones estudiadas la herencia del carácter en cuestión puede comportarse de manera diferente. La selección de individuos superiores dentro de las poblaciones puede ser realizada con base en el fenotipo, lo que posibilita la exploración de estos individuos dentro de los programas de mejoramiento para componer líneas o híbridos.

Palabras clave adicionales: Citrullus lanatus; características de la semilla; mejoramiento de cultivos; selección; codominancia incompleta.

Received for publication: 20-01-2020 Accepted for publication: 30-03-2020

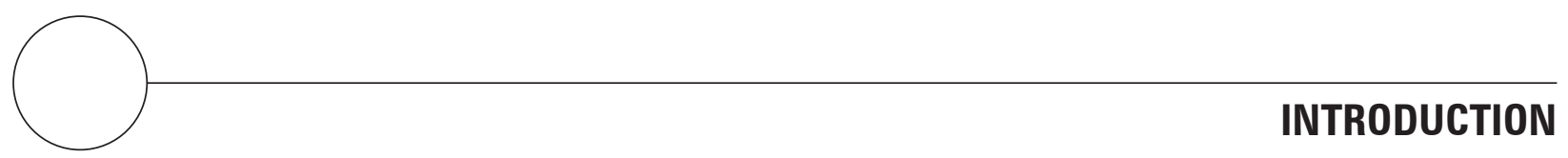

Watermelon [Citrullus lanatus (Thunb.) Matsum and Nakai] is one of the highest yielding fruit crops in Brazil, and according to the 2016 world ranking, the country was ranked as the $4^{\text {th }}$ largest watermelon producer, with 2,090,432 $\mathrm{t}$ of fruit, second only to China $(79,043,138$ t), Turkey $(3,928,892$ t) and Iran $(3,813,850 \mathrm{t})$ (Fao, 2018). The development of new genotypes with commercial attributes different from those already on the market, such as the size of the seeds, can make the production of Brazilian watermelon more expressive. Moreover, the consumer market has increasingly been demanding nutritious and healthy fruits (Farias et al., 2014).

For fresh consumption, the smaller the seed size, the easier it becomes to consume the fruit, while for the production of fruit and sowing in the field, the larger the seed size is, the greater the production and the easier the planting. Thus, understanding the genetic control of traits is important for the development of genotypes aimed at having the most diverse characteristics (Li et al., 2018). However, it is worth mentioning that information about the genetic behavior of watermelon characteristics is scarce. Among these reports, those studying the size of the seeds, besides being rare, are quite old, which characterizes it as being one of the main obstacles for breeders.

In previous studies, Poole et al. (1941), cited by Li et al. (2018), described that the genetic control of seed size was controlled by two genes, 's' and ' 1 ', with ' $s$ ' being epistatic to ' 1 '. A few years later, the ' $\mathrm{Ti}$ ' genes for tiny seeds and 'ti' genes for tomato seeds were described (Tanaka et al., 1995; Li et al., 2018). According to Yong et al. (2009), watermelon seed size can be classified as giant, large, medium, small, micro and tiny. In addition to seed size, inheritance studies of other characteristics in watermelon have been reported, including fruit yield (Kumar and Wehner, 2013), seed mass (Adjouman et al., 2016), resistance to the PRSV-W virus (Alves et al., 2014), and egusi seed (Gusmini et al., 2004). This suggests that before performing a characteristic improvement, it is necessary to understand the genetic control mechanisms within the populations of interest.

Thus, the objective of the present work was to study the inheritance of seed size characteristics in watermelon populations through crossing of contrasting genotypes. 


\section{MATERIALS AND METHODS}

\section{Obtaining the populations}

The experiment was conducted from 2017 to 2018 at the Bebedouro Experimental Station at Embrapa Semiárido in Petrolina-PE (Brazil). Two watermelon lines, with contrasting seed size, were used line 31715.001 (" $\mathrm{P}_{1}$ ") (small seed) and lineage 31717.005 $\left(" \mathrm{P}_{2}\right.$ ") (large seed), to obtain $\mathrm{F}_{1}, \mathrm{~F}_{2}, \mathrm{BC}_{1}$ and $\mathrm{BC}_{2}$ populations.

As such, crosses were carried out via controlled handpollination (CHP) according to the methods used by Nascimento et al. (2018). Regarding the CHP, in the flowering stage, male and female flowers of the lineages and the $\mathrm{F}_{1}$ hybrids were isolated at preanthesis using aluminum sachet bags. On the following day, the open male flowers were detached from the plants, their petals were removed to expose their anthers, and then pollen grains were gently deposited on the stigmas of the female flowers. After this procedure, the pollinated flowers were identified with cardboard tags containing information on the parental crossings, plant type, and CHP date. Afterward, the flowers were isolated again for a period of $72 \mathrm{~h}$. Between 30 and $35 \mathrm{~d}$ after pollination, the fruits were harvested, and their seeds were extracted, washed and left to dry in the shade.

To obtain the $\mathrm{F}_{1}$ population, between January and April 2017, seeds were sown in polystyrene trays containing proper commercial substrate and then kept in a greenhouse for $12 \mathrm{~d}$. After that period, the seedlings were transplanted to the field.

In the following generation, five seeds from the parents $\left(\mathrm{P}_{1}\right.$ and $\left.\mathrm{P}_{2}\right)$ and from the $\mathrm{F}_{1}$ population were sown during the months of May to August 2017, and using CHP, the $\mathrm{F}_{1}$ plants were self-fertilized and simultaneously crossed with the parents, $\mathrm{P}_{1}$ and $\mathrm{P}_{2}$, which produced the seeds of $\mathrm{F}_{2}, \mathrm{BC}_{1}$ and $\mathrm{BC}_{2}$ populations. All populations obtained were then evaluated in the field, from May to August 2018, under open pollination.

Fertilization was carried out according to a soil analysis and as recommended by Mendes et al. (2010), with $30 \mathrm{~kg} \mathrm{ha}^{-1}$ of $\mathrm{N}, 80 \mathrm{~kg} \mathrm{ha}^{-1}$ of $\mathrm{P}_{2} \mathrm{O}_{5}$, and $30 \mathrm{~kg}$ $\mathrm{ha}^{-1}$ of $\mathrm{K}_{2} \mathrm{O}$, plus $15 \mathrm{~kg} \mathrm{ha}^{-1}$ of $\mathrm{ZnSO}_{4}$ and $10 \mathrm{~kg} \mathrm{ha}^{-1}$ of $\mathrm{CuSO}_{4}$. Fertilizers were top-dressed with irrigation water containing $50 \mathrm{~kg} \mathrm{ha}^{-1}$ of $\mathrm{N}$ in the form of $\mathrm{Ca}$
$\left(\mathrm{NO}_{3}\right)_{2}$ and $40 \mathrm{~kg} \mathrm{ha}^{-1}$ of $\mathrm{K}_{2} \mathrm{O}$ using $\mathrm{KCl}$, between 50 to $60 \mathrm{~d}$ after sowing.

The water was applied by drip irrigation at a daily depth that varied according to the plants' needs depending on climatic conditions, monitored by a weather station located near the experimental area. The crop coefficients (Kc values) used to calculate crop evapotranspiration (ETc) were those obtained by Freitas and Bezerra (2004) in Canindé, CE, Brazil, for Crimson Sweet watermelon, whose corresponding values were 0.46 to 0.70 at the vegetative stage, 0.89 to 1.22 at the flowering stage, and 1.14 to 0.74 at the fruiting stage.

Phytosanitary treatments were carried out with agrochemicals registered by the Brazilian Ministry of Agriculture, Livestock and Supply, and weeds were removed manually.

\section{Phenotypes of seed size in watermelon populations}

During the months of April to August 2018, seeds from all the populations were germinated in expanded polystyrene trays containing commercial substrate for vegetables. At $12 \mathrm{~d}$ after sowing, the seedlings were transplanted into the field at the Bebedouro Experimental Station in accordance with a completely randomized design, with each plant considered an experimental unit and with a varied number for each population, in soil previously prepared with gray plastic mulching sheets, with $1 \mathrm{~m}$ spacing between plants and $2.5 \mathrm{~m}$ between rows. After transplanting, the seedlings were covered with an agrotextile blanket until the flowering period, at which point it was removed for pollination. The seeds of each population came from a single fruit.

At $70 \mathrm{~d}$ after planting, fruits were harvested. The seeds were subsequently extracted, washed and left to dry in the shade. Eight, 10, 7, 271, 95 and 94 plants from the $\mathrm{P}_{1}, \mathrm{P}_{2}, \mathrm{~F}_{1}, \mathrm{~F}_{2}, \mathrm{BC}_{1}$ and $\mathrm{BC}_{2}$ populations, respectively, were evaluated.

To investigate seed size inheritance, seed length was measured, as this characteristic is highly correlated with width and weight (Hawkins and Dane, 2001). The lengths of 10 seeds were measured with a digital caliper (Stainless Hardened: JL-YB5474) following the method used by Nascimento et al. (2018), with seeds randomly chosen from one fruit of each plant. 
The mean and variance $\left[\mathrm{P}_{1}\left(\sigma_{\mathrm{f}\left(\mathrm{P}_{1}\right)}^{2}=\sigma_{\mathrm{m}\left(\mathrm{P}_{1}\right)}^{2}=\sigma_{\mathrm{P}_{1}}^{2}\right)\right.$, $\mathrm{P}_{2} \quad\left(\sigma_{\mathrm{f}\left(\mathrm{P}_{2}\right)}^{2}=\sigma_{\mathrm{m}\left(\mathrm{P}_{2}\right)}^{2}=\sigma_{\mathrm{P}_{2}}^{2}\right), \quad \mathrm{F}_{1} \quad\left(\sigma_{\mathrm{f}\left(\mathrm{F}_{1}\right)}^{2}=\sigma_{\mathrm{m}\left(\mathrm{F}_{1}\right)}^{2}=\sigma_{\mathrm{F}_{1}}^{2}\right) ;$ $\mathrm{F}_{2}\left(\sigma_{\mathrm{f}\left(\mathrm{F}_{2}\right)}^{2}=\sigma_{\mathrm{g}\left(\mathrm{F}_{2}\right)}^{2}+\sigma_{\mathrm{m}\left(\mathrm{F}_{2}\right)}^{2}\right), \quad \mathrm{BC}_{1}\left(\sigma_{\mathrm{f}\left(\mathrm{BC}_{1}\right)}^{2}=\sigma_{\mathrm{g}\left(\mathrm{BC}_{1}\right)}^{2}+\sigma_{\mathrm{m}\left(\mathrm{BC}_{1}\right)}^{2}\right)$ and $\left.\mathrm{BC}_{2}\left(\sigma_{\mathrm{f}\left(\mathrm{BC}_{2}\right)}^{2}=\sigma_{\mathrm{g}\left(\mathrm{BC}_{2}\right)}^{2}+\sigma_{\mathrm{m}\left(\mathrm{BC}_{2}\right)}^{2}\right)\right]$ of the populations were then estimated.

The mean degree of dominance (MDD) of the characteristic was estimated based on the variances and in accordance with the model $\mathrm{MDD}=$ $2 \bar{F}_{1}-\left(\bar{P}_{1}+\bar{P}_{2}\right) / \bar{P}_{1}-\bar{P}_{2}$. Broad-sense $\left(h_{a}^{2}\right) \quad(1)$ and narrow-sense $\left(h_{\mathrm{r}}^{2}\right)(2)$ heritability were estimated as follows:

$$
\begin{gathered}
h_{a}^{2}=\frac{\sigma_{\mathrm{g}\left(\mathrm{F}_{2}\right)}^{2}}{\sigma_{\mathrm{f}\left(\mathrm{F}_{2}\right)}^{2}}=\frac{\sigma_{\mathrm{f}\left(\mathrm{F}_{2}\right)}^{2}-\left(\sigma_{\mathrm{P}_{1}}^{2}+2 \sigma_{\mathrm{F}_{1}}^{2}+\sigma_{\mathrm{P}_{2}}^{2}\right) / 4}{\sigma_{\mathrm{f}\left(\mathrm{F}_{2}\right)}^{2}} \\
h_{\mathrm{r}}^{2}=\frac{\sigma_{\mathrm{a}}^{2}}{\sigma_{\mathrm{f}_{\left(\mathrm{F}_{2}\right)}}^{2}}=\frac{2 \sigma_{\mathrm{f}\left(\mathrm{F}_{2}\right)}^{2}-\left[\sigma_{\mathrm{f}\left(\mathrm{BC}_{1}\right)}^{2}+\sigma_{\mathrm{f}\left(\mathrm{BC}_{2}\right)}^{2}\right]}{\sigma_{\mathrm{f}\left(\mathrm{F}_{2}\right)}^{2}}
\end{gathered}
$$

Additionally, the values of $k 1$ (based on variance) and k2 (based on the mean) were estimated, where $\mathrm{k}=0$ indicates the absence of dominance $(\mathrm{k}=0=$ additive), $0 \geq \mathrm{k} \leq 1$ indicates incomplete dominance, $\mathrm{k}>1$ indicates over dominance, and $\mathrm{k}=1$ indicates complete dominance.

Additionally, the minimum number of genes (MNG) controlling the characteristic was estimated by the formula $n=\left(\bar{P}_{1}+\bar{P}_{2}\right)^{2} / 8\left[\sigma_{\mathrm{g}(\mathrm{F} 2)}^{2}\right]$. In terms of computer resources, the "segregating and non-segregating generations" procedure of the GENES software program was used (Cruz, 2016).

Afterward, the characteristic mean was subjected to the chi-square $\left(X^{2}\right)$ test at a 0.05 significance level for verification of the mendelian pattern within the $\mathrm{F}_{2}$ population according to the following model (3):

$$
x^{2}=\sum_{i=1}^{n}\left[\frac{\left(O b s_{i}-E s p_{i}\right)^{2}}{E s p_{i}}\right]
$$

where $X^{2}$ is the chi-square value calculated and $\mathrm{Obs}_{i}$ and $E s p_{i}$ are the observed and expected frequencies of the $i$-th phenotypic class $(i=1,2, \ldots, \mathrm{n})$, respectively (Schuster and Cruz, 2013).

\section{RESULTS AND DISCUSSION}

The mean, variance and standard deviation of the seed length of the parents of the segregating populations (Tab. 1) were different, which indicated the existence of genetic variability between them.

The results are in line with the assumption of Cruz et al. (2014), who stated that better precision in genetic analyses requires parents whose studied characteristics contrast. According to those authors, genetic parameter estimates allow the identification of the nature of the action of the genes involved in characteristic control. Thus, estimates can be used as an advantageous auxiliary tool in breeding program management.

The variance expressed by the parents and the hybrids showed low values, while the $\mathrm{F}_{2}$ and $\mathrm{RC}_{2}$ populations presented high values. Similar results were reported by Souza et al. (2006), who, when studying seed size inheritance in watermelon generations, observed high values of variance in the $\mathrm{F}_{2}$ and $\mathrm{BC}_{2}$ populations. The high values in both studies possibly occurred because gene segregation within these populations is higher than in the other populations.

Although watermelon is an allogamous species, the low values of variance in the $\mathrm{P}_{1}, \mathrm{P}_{2}$ and $\mathrm{F}_{1}$ populations of the present study are due to environmental factors, since the parents used to develop the segregating populations were generated by seven cycles of self-fertilization. Thus, each of the plants of these generations is considered to correspond to the same

\begin{tabular}{|c|c|c|c|c|}
\hline Generation (seed size) ${ }^{1}$ & Number of individuals & Mean & Variance & Standard deviation \\
\hline $\mathrm{P}_{1}$ (small) & 8 & 5.90 & 0.0286 & 0.17 \\
\hline $\mathrm{P}_{2}$ (largest) & 10 & 11.63 & 0.0934 & 0.31 \\
\hline $\mathrm{F}_{1}$ (medium) & 7 & 6.89 & 0.0214 & 0.15 \\
\hline$F_{2}(1 / 4$ small, $1 / 2$ medium and $1 / 4$ largest) & 271 & 7.71 & 5.4044 & 2.32 \\
\hline $\mathrm{BC}_{1}(1 / 2$ small and $1 / 2$ medium) & 95 & 6.24 & 0.2474 & 0.50 \\
\hline $\mathrm{BC}_{2}(1 / 2$ medium and $1 / 2$ largest) & 94 & 9.68 & 5.4711 & 2.34 \\
\hline
\end{tabular}
genotype. However, expecting higher values of the

Table 1. Number of plants, means, variance and standard deviations of seed size, as evaluated for six watermelon populations.

${ }^{1}$ Seed size in populations. 
variance of $\mathrm{F}_{2}$ populations and backcross generations due to the interaction of genetic and environmental factors influences the phenotypic expression of traits (Cruz et al., 2014).

The $\mathrm{F}_{2}$ population presented the fourth lowest mean. According to Zewdie and Bosland (2000), depending on the interaction of a trait, the mean for this population may increase or decrease, indicating that parents are contributing alleles to increase or decrease the trait under study. Based on this information, the mean value of the $\mathrm{F}_{2}$ population may have occurred because most seeds were classified as medium and short, which together represent approximately $75 \%$ of the total amount.

According to the genetic parameter estimates for the $\mathrm{F}_{2}$ population (Tab. 2), in comparison with the environmental variance, the genetic variance had the greatest influence. Nascimento (2017) found similar results for watermelon seed size, with a higher genetic variance than environmental variance. These results show that the environment has little influence on the phenotypic expression of the evaluated characteristic and that the phenotype observed was mostly the result of genetic influence.

Table 2. Genetic parameters related to seed size in a watermelon $F_{2}$ population obtained by crossing contrasting varieties.

\begin{tabular}{|l|c|}
\hline \multicolumn{1}{|c|}{ Parameter } & Value \\
\hline Phenotypic variance $\left(\sigma_{p}^{2}\right)$ & 5.404 \\
\hline Environmental variance $\left(\sigma_{e}^{2}\right)$ & 0.041 \\
\hline Genotypic variance $\left(\sigma_{g}^{2}\right)$ & 5.363 \\
\hline Additive variance $\left(\sigma_{a d}^{2}\right)$ & 5.090 \\
\hline Variance of dominance deviation $\left(\sigma_{d}^{2}\right)$ & 0.273 \\
\hline Broad-sense heritability $\left(h_{a}^{2}\right)$ & 99.237 \\
\hline Narrow-sense heritability $\left(h_{r}^{2}\right)$ & 98.189 \\
\hline Mean degree of dominance (MDD) & 0.327 \\
\hline K values & $\mathrm{k} 1(0.33)$ and k2 (0.66) \\
\hline $\begin{array}{l}\text { Minimum number of genes controlling } \\
\text { the characteristic }(\mathrm{MNG})\end{array}$ & 1.82 \\
\hline Maximum value & 12.8 \\
\hline Minimum value & 4.2 \\
\hline
\end{tabular}

The estimates of the phenotypic, genotypic, additive and environmental variances showed that the contribution of the additive-effect genes to the dominance genes in terms of seed size was significant (Tab. 2), indicating additive allelic interaction. Corroborating the results of the present study, Tanaka et al. (1995), when examining the inheritance of fruit shape and seed size in two contrasting watermelon populations, also observed that seed size was governed predominantly by additive allelic interaction, with the small-seed phenotype being an easily improved characteristic.

However, Adjoumani et al. (2016), when studying the genetics of seed traits resulting from the intraspecific crossbreeding of distinct watermelon varieties, observed that the effects of genes for the characteristic in question showed dominant allelic interactions. The differing results reported by the above authors can be attributed to the genetic differences of the populations evaluated in each study.

It is worth emphasizing that the predominance of additive allelic interaction facilitates the selection stage, since superior individuals also show superior descent (Cruz et al., 2014). Regarding dominant allelic interactions, breeding programs can benefit from developing hybrids.

Within the $\mathrm{F}_{2}$ population, one superior individual was observed for the smallest seed size $(4.2 \mathrm{~mm})$ (Tab. 2). This individual can be further investigated and give rise to a small-seed open-pollinated cultivar and can also produce a small-seed-size variety, which can be used for hybrid combinations that may result in reduced-seed-size genotypes. It is worth noting that small seed size is dominant over large seed size, and medium size is dominant over small and large sizes (Guner and Wehner, 2004).

The use of transgressive genotypes to develop hybrids with reduced seed size can be very promising, as producers may be able to acquire hybrid seeds of relatively large size, making planting easier, whereas the fruits of these hybrids will have relatively small seeds, thus making watermelon consumption more agreeable and providing a market advantage over the other genotypes.

In the present study, individuals from the $\mathrm{F}_{2}$ population presented the following approximate phenotypic percentages of seed size: small (25\%), medium $(50 \%)$ and large (25\%). Previous inheritance studies on watermelon seed traits such as weight showed that monogenic segregation at a 3:1 ratio did not occur as expected but was close enough to suggest that 
the smallest seed mass was monogenic and dominant over the largest seed mass (Weetman, 1937).

Similar results were observed in the present study for seed size, where the smallest size, although not in accordance with the expected 3:1 ratio, was quite close to a ratio of 1:2:1, thus suggesting that the characteristic is controlled by two genes.

In addition, the seed size characteristic showed high broad-sense and narrow-sense heritability (Tab. 2). Similar results were observed by Amburani (2018), who, when studying the heritability of morphoagronomic traits in 30 watermelon genotypes, obtained heritability estimates of more than $80 \%$ for seven of the 13 traits evaluated, including 100-seed weight and number of seeds per fruit. According to Cruz et al. (2014), narrow-sense heritability represents the variance of the additive type fixed in the populations as a result of the advancement of generations. Based on this information, the correlation between phenotypic values and genetic values is considered high for the characteristic in question, and it is possible to select individuals with relatively small seed sizes based on their phenotype.

To infer the mean degree of dominance and determine the best strategy to improve various characteristics, the values of $\mathrm{k} 1$ (0.33) and k2 (0.66) (Tab. 2 ) were calculated and showed mutual agreement, indicating the existence of incomplete dominance for seed size in the studied populations. Adjoumani et al. (2016), when studying the genetics of seed traits resulting from the intraspecific crossing of distinct watermelon varieties, obtained the same results. In both studies, these results reinforce the efficiency of genotype selection of individuals of interest based on the phenotype.
The minimum value for the number of genes involved in the control of the studied characteristic was 1.82 (Tab. 2). This information is important for estimating the type of inheritance that controls a given characteristic (Lobo et al., 2005). In the present study, seed size is controlled by two genes, indicating that simpler breeding methods, such as mass selection, can be used to obtain small-seed-size cultivars.

When we performed the chi-square test on the populations (Tab. 3), there were no significant differences between populations for observed and expected frequencies associated with phenotypic segregation of the $\mathrm{BC}_{1}$ population, in which all individuals should present the same seed size. However, it was observed that the seeds of the individuals were divided into small and medium sizes, confirming the hypothesis by which two genes control the characteristic under incomplete dominance.

Similarly, Poole et al. (1941), cited by Prothro et al. (2012) studied seed length inheritance by evaluating crosses between plants that produce small and large, small and medium, and medium and large seeds and proposed that this characteristic is controlled by two genes because medium-size seeds were dominant over small- and large-size seeds. Those authors proposed that the recessive $l$ and $s$ genes afforded largeand small-seed phenotypes, respectively. In addition, among the evaluated genotypes, the $s$ gene was epistatic for $l$, and $L L S S$ was assigned to medium-size seeds; II SS, large-size seeds; and LL ss or 11 ss, smallsize seeds.

On the other hand, Tanaka et al. (1995) proposed that, in a Sweet Princess watermelon population, tiny seed size was monogenic, controlled by the $T i$ gene and dominant over medium seed size; thus, the

Table 3. Chi-square test results of the watermelon populations to investigate the segregation of two loci based on the 1:2:1 ratio.

\begin{tabular}{|c|c|c|c|c|c|c|c|c|c|}
\hline \multirow{2}{*}{ Generation } & \multicolumn{3}{|c|}{ Observed } & \multicolumn{3}{|c|}{ Expected } & \multirow{2}{*}{$x^{2}$} & \multirow{2}{*}{$\mathrm{DF}$} & \multirow{2}{*}{$\mathrm{P}$} \\
\hline & Small & Medium & Large & Small & Medium & Large & & & \\
\hline$P_{1}$ & 8 & 0 & 0 & 8.0 & 0 & 0 & - & - & - \\
\hline $\mathrm{P}_{2}$ & 0 & 0 & 10 & 0 & 0 & 10.0 & - & - & - \\
\hline$F_{1}$ & 0 & 7 & 0 & 0 & 7.0 & 0 & - & - & - \\
\hline $\mathrm{F}_{2}$ & 64 & 130 & 49 & 67.75 & 135.5 & 67.75 & $5.62^{\text {ns }}$ & 2 & 0.05 \\
\hline $\mathrm{BC}_{1}$ & 45 & 50 & 0 & 47.5 & 47.5 & 0 & $0.263^{\text {ns }}$ & 1 & 0.05 \\
\hline
\end{tabular}

${ }^{n s}$ not significant at the 0.05 significance level (P) by the chi-square test (X2); DF: degrees of freedom. 
tiny seed size characteristic was possibly governed by simple inheritance.

The differences observed in the results of the present study possibly show that, for the characteristic in question and depending on the cultivars involved in the crosses, inheritance may behave differently with respect to the populations under study, so it is not possible to extrapolate these results to other populations. Furthermore, the method adopted here for seed size measurement was quantitative, expressed in millimeters, while the study by Polle et al. (1941) categorized seed size into classes; that is, they performed a qualitative assessment, disregarding minimal size differences and limiting the population.

The results obtained by means of the predicted gain from selection (Tab. 4) reinforce that, for the improvement of the characteristic under study, the use of simpler breeding methods can be effective, since the gain from the selection was $59 \%$ for relatively large seeds and a decrease of just under 30\% for relatively small ones. In other words, it is possible to select and recombine individuals that produce large seeds and small seeds, seeking to develop hybrid combinations that produce seeds of intermediate size; this is in addition to the possibility of exploiting these individuals to develop new cultivars for different purposes.

Table 4. Predicted gain from selection for seed size in a watermelon $F_{2}$ population obtained by crossing contrasting varieties.

\begin{tabular}{|l|c|c|}
\hline \multirow{2}{*}{\multicolumn{1}{|c|}{ Parameters }} & \multicolumn{2}{c|}{ Selection } \\
\cline { 2 - 3 } & Highest values & Lowest values \\
\hline MSI & 12.577 & 5.285 \\
\hline S & 4.870 & -2.422 \\
\hline GS (\%) & 59.516 & -29.605 \\
\hline PM 1 ${ }^{\circ} \mathrm{S}$ & 12.294 & 5.425 \\
\hline
\end{tabular}

MSI: mean of selected individuals; S: selection differential; GS (\%): gain from selection (in percentage), and $\mathrm{PM} 1^{\circ} \mathrm{S}$; predicted mean for a selection cycle.

\section{CONCLUSIONS}

In the present work, inheritance of the smallest seed size trait in the studied populations is controlled by two genes with incomplete dominance;

Depending on the population under study, the inheritance behavior for the seed size characteristic may behave differently.
Selection of superior individuals for the smallest seed size within an $\mathrm{F}_{2}$ population can occur based on phenotype;

Increased numbers of individuals can be exploited within breeding programs to develop lines or hybrids.

\section{ACKNOWLEDGMENTS}

To the Coordination for the Improvement of Higher Education Personnel (CAPES) for the granting. The author is grateful to Fundação de Amparo à Pesquisa do Estado da Bahia (FAPESB - Bahia Research Foundation) for the doctoral scholarship granted; to Embrapa Semiárido (a unit of the Brazilian Agricultural Research Corporation) for the partnership and the infrastructure made available; to the Graduate Program in Plant Genetic Resources (PGGRGV) of the State University of Feira de Santana for support in the courses; and to the Embrapa Semiárido trainees and the Biological Sciences undergraduates at the University of Pernambuco (UPE), Karina Branco, Jackson, Ingrid Caroline, Débora Eduarda and André Granja for their help in the experiment evaluations.

Conflict of interests: The manuscript was prepared and reviewed with the participation of the authors, who declare that there exists no conflict of interest that puts at risk the validity of the presented results.

\section{BIBLIOGRAPHIC REFERENCES}

Adjoumani, K., S.B. Bony, G.K. Koffi, L.C. Kouonon, F.K. Brou, and R. Sié. 2016. Genetic evaluation of seed traits from intraspecific crossing of genetically distinct watermelon varieties. Afr. Crop Sci. J. 24(2), 143154. Doi: 10.4314 /acsj.v24i2.3

Alves, A.F., I.R. Nascimento, C.A. Ticona-Benavente, M.V. Faria, R.A. Sarmento, A.R. Figueira, and W.R. Maluf. 2014. Herança da resistência do acesso de melancia PI 595201 a isolado de PRSV-W do Estado do Tocantins. Bragantia 73(2), 138-142. Doi: 10.1590/brag.2014.022

Amburani, A. 2018. Studies on genetic variability and genetic advance for yield parameters in watermelon ( $\mathrm{C} i$ trullus lanatus Thumb.). Asian J. Hortic. 13(2), 39-44. Doi: 10.15740/HAS/TAJH/13.2/39-44

Cruz, C.D. 2016. Genes Software - extended and integrated with the R, Matlab and Selegen. Acta Sci.-Agron. 38 (4), 547-552. Doi: 10.4025/actasciagron.v38i3.32629

Cruz C.D., P.C.S. Carneiro, and A.J. Regazzi. 2014. Modelos biométricos aplicados ao melhoramento genético. $4^{\text {th }}$ ed. Universidade Federal de Viçosa, Viçosa, Brazil. 
FAO. 2018. FAOSTAT - Production crops. In: http://www. fao.org/faostat/es/\#data/QC; consulted: June, 2019.

Farias, R.M., C.F. Barreto, R.R. Zandoná, J.P. Rosado, and C.R. Martins. 2014. Comportamento do consumidor de frutas na região da fronteira Oeste do Rio Grande do Sul com Argentina e Uruguai. Rev. Bras. Frutic. 36(4), 872-883. Doi: 10.1590/0100-2945-417/13

Freitas, A.A. and F.M.L. Bezerra. 2004. Coeficientes de cultivo para melancia nas suas fases fenológicas. Rev. Ciênc. Agron. 35(2), 319-325.

Guner, N. and T.C. Wehner. 2004. The genes of watermelon. HortScience 39(6), 1175-1182. Doi: 10.21273/ HORTSCI.39.6.1175

Gusmini, G., T.C. Wehner, and R.L. Jarret. 2004. Inheritance of Egusi seed type in watermelon. J. Hered. 95(3), 268-270. Doi: 10.1093/jhered/esh031

Hawkins, L.K. and F. Dane. 2001. Molecular markers associated with morphological traits in watermelon. HortScience 36(7), 1318-1322. Doi: 10.21273/ HORTSCI.36.7.1318

Kumar, R. and T.C. Wehner. 2013. Quantitative analysis of generations for inheritance of fruit yield in watermelon. Hortscience 48(7), 844-847. Doi: 10.21273/ HORTSCI.48.7.844

Li, N., J. Shang, J. Wang, D. Zhou, N. Li, and S. Ma. 2018. Fine mapping and discovery of candidate genes for seed size in watermelon by genome survey sequencing. Sci. Rep. 8(17843), 1-11. Doi: 10.1038/ s41598-018-36104-w

Lobo, V.L.S., L.B. Giordano, and C.A. Lopes. 2005. Herança da resistência à mancha bacteriana em tomate. Fitopatol. Bras. 30(4), 343-349. Doi: 10.1590/ S0100-41582005000400002

Mendes, A.M.S., C.M.B. Faria, and D.J. Silva. 2010. Adubação. In: Dias, R.C.S., G.M. Resende, and N.D. Costa (eds.). Sistema de produção de melancia. In: Embrapa Semiárido, https://sistemasdeproducao.cnptia.embrapa.br/FontesHTML/Melancia/SistemaProducaoMelancia/adubacao.htm; consulted: April, 2019.
Nascimento, T.L. 2017. Divergência genética, capacidade de combinação e heterose em melancia. $\mathrm{PhD}$ thesis. Universidade Federal Rural de Pernambuco, Recife, Brazil.

Nascimento, T.L., F.F. Souza, R.C.S. Dias, and E.F. Silva. 2018. Agronomic characterization and heterosis in watermelon genotypes. Pesqui. Agropecu. Trop. 48(2), 170-177. Doi: 10.1590/1983-40632018v4851779

Poole, C.F., P.C. Grimball, and D.R. Porter. 1941. Inheritance of seed characters in watermelon. J. Agric. Res. 63(3), 433-456.

Prothro, J., K. Sandlin, and H. Adel-Haleem. 2012. Main and epistatic quantitative trait loci associated with seed size in watermelon. J. Am. Soc. Hortic. Sci. 137(6), 452-457. Doi: 10.21273/JASHS.137.6.452

Schuster, I. and C.D. Cruz. 2013. Estatística genômica aplicada a populações derivadas de cruzamentos controlados. $2^{\text {nd }}$ ed. Universidade Federal de Viçosa, Viçosa, Brazil.

Souza, F.F., E.B.A. Souza, A.C. Silva, L.R.S. Neves, R.C.S Dias, and M.A. Queiróz. 2006. Estudo de herança do tamanho da semente em melancia. pp. 1613-1616. In: Proc. 46 Congresso Brasileiro de Olericultura. Associação Brasileira de Horticultura (ABH), Goiânia, Brazil.

Tanaka, T., S. Wimol, and T. Mizutani. 1995. Inheritance of fruit shape and seed size of watermelon. J. Jpn. Soc. Hortic. Sci. 65(3), 543-548. Doi: 10.2503/jjshs.64.543

Weetman, L.M. 1937. Inheritance and correlation of shape, size, and color in the watermelon, Citrullus vulgaris Schrad. Res. Bull: Iowa Agriculture and Home Economics Experiment Station 20(228), 222-256.

Yong-Jae, K., Y. Tae-Jin, P. Young-Hoon, L. Yong-Jik, K. Sun-Cheol, K. Yong-Kwon, and C. Jeoung-Lai. 2009. Development of near isogenic lines with various seed sizes and study on seed size-related characteristics in watermelon. Korean J. Breed. Sci. 41(4), 403-411.

Zewdie, Y. and P. Bosland. 2000. Capsaicinoid inheritance in an interspecific hybridization of Capsicum annuum 9 C. chinense. J. Am. Soc. Hortic. Sci. 125(4), 448-453. Doi: 10.21273/JASHS.125.4.448 